\title{
The Effect of Scientific Approach and Interpersonal Interaction of Islamic Education to Student Characters in Integrated Islamic School Al Hafiz Langkat District
}

\author{
Amiruddin Siahaan', ${ }^{1}$ Hafsah $^{2}$, Satria Mandala ${ }^{3}$ \\ ${ }^{1,2}$ Faculty of Tarbiyah and Teacher Training, Universitas Islam Negeri Sumatera Utara, Indonesia \\ ${ }^{3}$ Postgraduate Program in Faculty of Tarbiyah and Teacher Training, Universitas Islam Negeri Sumatera \\ Utara, Indonesia \\ satria.fatih17@gmail.com
}

\begin{abstract}
The purpose of this research are to find out: (1) the scientific approach has a significant influence on student character, (2) interpersonal interaction has a significant effect on student character, and (3) the effect of scientific approach and interpersonal interaction together on student character. The research method used was quasi experiment with $2 \times 2$ factorial designs. The sampling technique used was cluster random sampling. Data collection instruments are questionnaires and tests. Data analysis technique used two-way analysis of variance. The research findings show: (1) there is a positive and significant influence between the scientific learning approach and student character, (2) there is a positive and significant effect between interpersonal interactions in the learning of Islamic Education with student character, and (3) there is a positive and significant effect between scientific approach and interpersonal interaction on learning Islamic Education with student character.
\end{abstract}

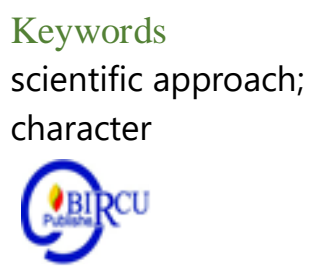

\section{Introduction}

The implementation of the 2013 curriculum is characterized by a very fundamental change in the learning process, namely learning that emphasizes active learning. with a scientific approach as the main approach that needs to be strengthened by discovery learning, inquiry learning, and project based learning.

Standards The learning process with a scientific approach includes the steps: observing, asking, trying, associating, communicating, and creating. In reality there are still many teachers who face difficulties to implement these steps in accordance with the subjects taught. This shows that the teacher has not been able to understand well the concept of these learning steps. Therefore, the writing of this material is intended to provide an explanation of the concept of scientific learning and its application in learning, with examples for learning Islamic education.

Furthermore, related to the learning process, communication is said to be effective if the subject matter can be accepted and understood and provides positive feedback from students. Effective communication in learning must be supported by interpersonal communication skills that must be possessed by a teacher. Interpersonal communication is communication that takes place informally between two individuals. This communication goes from heart to heart, because between the two parties there is a relationship of mutual trust. 


\section{Review of Literatures}

Daryanto (2014: 51) explains learning with a scientific approach is a learning process designed in such a way that students actively construct concepts, laws or principles through stages of observing (to identify or find problems), formulate problems, propose or formulate hypotheses, collecting data with various techniques, analyzing data, drawing conclusions and communicating the concepts, laws or principles found. In learning, students are encouraged to discover for themselves and transform complex information, check new information with what is already in their memories and develop into information or abilities that are appropriate to the environment, era, place, and time they lived.

The scientific approach is an approach in learning activities that prioritizes students' creativity and findings. According to Kosasih (2014: 72) the characteristics of scientific learning are as follows: (1) Learning material is understood with logical standards that are appropriate to the level of maturity, but it is also possible for students to criticize, know the acquisition procedure, even their weaknesses, (2) learning interactions take place openly and objectively. Students have the broadest opportunity to express their thoughts, feelings, attitudes, and experiences. But students still pay attention to scientific attitudes and responsibilities, and (3) Students are encouraged to always think analytically and critically. Accurately in understanding, identifying, solving problems, and applying learning materials. The scientific approach is very focused on students in the learning process. The cognitive process of students will develop because students are directly involved in learning both in the classroom and outside the classroom.

Scientific approach is also called the scientific approach. This is in line with the implementation of the 2013 curriculum, which is required by the government. The approach that must be applied in schools is to apply the 2013 curriculum. This is in accordance with Permendikbud number 20 of 2016 concerning the Basic and Secondary Education Process Standards which has hinted at the need for a guided learning process with the principles of scientific/ scientific approach (Regulation of the Minister of Education and Culture of the Republic of Indonesia Number 20 concerning Basic and Secondary Education Process Standards, 2016: 1).

The principles of scientific learning, namely: (1) student-centered learning, (2) learning forms student self concept, (3) learning avoids verbalism, (4) learning encourages an increase in students' thinking abilities, (5) learning increases student interpersonal interactions and teacher motivation to teach, (6) provide opportunities for students to practice communication skills, and (7) the process of validation of concepts, laws and principles constructed by students in their cognitive structures. (Daryanto, 2014: 58).

This scientific approach is intended to provide understanding to students in knowing, understanding various materials using a scientific approach, that information can come from anywhere, anytime not dependent on the direction of information from the teacher. Therefore, the expected learning conditions created are directed to encourage students to find out from various sources of observation (Majid and Rochman, 2014: 69-70).

Taylor (1999:26) defines interpersonal communication as communication between two people that takes place face-to-face that is spontaneous, informal, receives mutual feedback (reciprocity) to the maximum and participation plays a flexible role. Littlejohn (1998: 31) provides a definition of interpersonal communication (interpersonal communication) is communication between individuals. Hardjana (2003: 85) said interpersonal communication is a face-to-face interaction between two or several people, 
where the sender can deliver the message directly and the recipient of the message can receive and respond directly as well.

According to Mulyana (2008:85) said that, "interpersonal communication or interpersonal communication is communication between people face to face that allows each participant to capture other people's reactions directly both verbally and nonverbally".

Another definition put forward by Muhammad (2005:153) interpersonal communication is the process of exchanging information between a person with at least one other person or usually between two people who can be directly identified (direct communication.

Hardjana (2003:77) explains interpersonal communication can be said to be effective if the message is received and understood as intended by the sender of the message, the message is followed up with a voluntary act by the recipient of the message, can improve the quality of interpersonal relationships and there are no obstacles to it.

Narwanti (2011:2) argues that: character is a dynamic organization of psychophysical systems that determine the behavior and thoughts of individuals specifically. Psycho-physical interactions direct human behavior. Character is not just a personality (personality) because the real character is a personality that is valued (personality evaluated).

Azzet (2011: 29) in character education, students are intentionally built so that their characters have good values while practicing them in daily life, be it to the Almighty God, himself, fellow human beings, the environment, nation, state and international relations as fellow citizens of the world.

The purpose of character education is explained by Narwanti (2011: 16-17): facilitating the reinforcement and development of certain values so that they are manifested in children's behavior, both during the school process and after the school process. Correcting student behavior that is incompatible with the values developed in school, building harmonious connections with families and communities in playing the responsibility of character education together.

\section{Research Methods}

This research uses a quasi experiment method with a $2 \times 2$ factorial design. The sampling technique is used cluster random sampling in this case selected class IV-a as the expriment class) and class IV-d as the control class. Data collection instruments used were questionnaires and tests, while the data analysis technique used was two-way analysis of variance.

\section{Discussion}

The results showed that there was a positive influence between the scientific approach and the character of students in learning Islamic Education obtained $r_{\text {count }}$ value of 0.703 and $r_{\text {table }}$ of 0.361 , in accordance with the provisions that said significant effect if

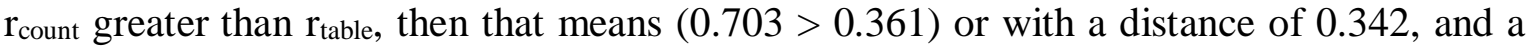
significance value of 0,000 , meaning less than $0.05(0,000<0.05)$. Effective contribution to the variable of teaching creativity is $49.42 \%$. The results of this study are in accordance with the opinion of Djamarah (2010:68) that the factors that influence the level of student character are the only instrumental factors in the form of a scientific approach. 
In the learning process in accordance with its development, the teacher not only has a role to provide information to students, but furthermore the teacher can act as a planner, regulator and encouraging students to learn effectively and the next role is to evaluate the overall teaching and learning process. So in any situation and condition the teacher in realizing the teaching and learning process is required to take a scientific approach so that the character of students increases.

Thus, a teacher's scientific approach to teaching will determine good character or character. The better the teacher in making a personal approach to teaching, the student's character in learning will also proceed according to expectations.

The results showed that there was a positive and significant relationship between interpersonal interactions with learning Islamic Education obtained $r_{\text {count }}$ value of 0.694 and $r_{\text {table }}$ of 0.361 , in accordance with the provisions that are said to be significantly related when $r_{\text {count }}$ is greater than $r_{\text {table, }}$, then that means $(0.694>0.361)$ or with a distance of 0.333 and a significance value of 0.000 , which means less than $0.05(0.000<0.05)$. The effective contribution of interpersonal interactions is $48.16 \%$.

Motivation is a conscious effort to influence a person's behavior so that he or she is moved to act to achieve certain results or goals (Purwanto, 2002: 71). In general, motivation aims to move a person to arise the desire and willingness to do something so that it can get results or achieve certain goals. According to Mulyasa (2003), to arouse students' interpersonal interactions, teachers need to pay attention to things including the students will study harder if the topic being studied is interesting and useful for themselves, learning objectives must be clearly arranged and informed to students, students must always be informed about the results of learning, giving praise and gifts are better than punishment, but at any time punishment is also needed, utilizing the attitudes, ideals and curiosity of students, and so on.

Interpersonal interaction of students determines the achievement of learning. The existence of motivation in students makes these students not easily discouraged, persevering and always competing to be the best. For this reason, based on good interpersonal interaction, it can cause awareness in students to always learn of their own volition without coercion from others. If there is already awareness in students, then students will be easier to understand the material presented, making it easier for students to achieve the desired learning outcomes.

The results showed that there was a positive and significant relationship between teaching creativity and interpersonal interaction with learning Islamic Religious Education obtained $r_{\text {count }}$ value of 0.782 and $r_{\text {table }}$ of 0.361 , in accordance with the provisions that were said to be significantly related when $r_{\text {count }}$ was greater than $r_{\text {table, }}$, then that meant $(0.782>0.361)$ or with a distance of 0.421 and a significance value of 0.000 , which means less than $0.05(0.000<0.05)$. Scientific learning variables and interpersonal interaction variables together contributed to the character of students by $61.15 \%$.

Learning is a business process undertaken to obtain a new change in behavior as a whole, as a result of his own experience in his interactions with his environment. The learning process that has been carried out will certainly obtain learning outcomes, to determine the level of student success one parameter is used, namely the level of learning that students get. 


\section{Conclusion}

The conclusions that can be drawn are: (1) there is a positive and significant influence between the scientific learning approach and the character of students, this is evidenced from the rcount value greater than rtable $(0.703>0.361)$ and a significance value of 0.000 , which means less than $0,05(0,000<0.05)$, (2) there is a positive and significant influence between the interpersonal interactions of Islamic Education learning with the character of students, this is evidenced from the rcount value greater than rtable $(0.694>0.361)$ and the significance value of 0.000 , which means less than $0.05(0,000<$ $0.05)$, and (3) there is a positive and significant influence between the scientific approach and the interpersonal interaction of Islamic religious education learning with student characters, this is evidenced from the rcount value of 0.740 greater than rtable $(0.740>$ $0.361)$ and a significance value of 0.000 , which means less than $0.050(0.000<0.05)$.

Based on the discussion and conclusion above, some suggestions can be given as follows: (1) teachers should be able to apply a scientific approach oriented to the form of an active learning approach where students as student centers and teachers as their directors to foster children's intellectual development, self-confidence, soul creative, and active and critical soul in learning and values in children by approaching, so as to build awareness in students to learn well thereby achieving shared characters, (2) considering interpersonal interactions have an influence on the character of students, teachers pengenal continue to try to establish interpersonal interactions with students so that a teacher's concern for their students arises and good verbal and non-verbal communication is established, and (3) it is recommended that the next researcher be able to research more deeply about variables related to character For example students are associated with factors of flexibility and openness in the teaching and learning process and other factors so as to perfect this research.

\section{References}

Amelia, L., Hayati, F., Milfayetti, S., and Ichsan. 2019. Analysis of the Use of Kindergarten Watching Siaga Bencana Learning Model for Structured Positive Thinking Ability on Early Childhood Budapest International Research and Critics Institute-Journal (BIRCI-Journal) (2): 379-387.

Ananda, Rusydi. 2019. Desain Pembelajaran. Medan: LPPPI

Azzet, Akhmad Muhaimin. 2011. Urgensi Pendidikan Karakter di Indonesia : Revitalisasi

Pendidikan Karakter terhadap Keberhaslan Belajar dan kemajuan Bangsa.Yogyakarta: Ar-Ruzz Media

Taylor dan Bogdan, 1999. Pengaturan Koordinasi Pemerintahan di Daerah, Aditya, Bandung.

Daryanto. 2014. Pendekatan Pembelajaran Saintifik. Yogyakarta: Gava Media.

Kementerian Pendidikan dan Kebudayaan Republik Indonesia. 2016. Panduan Penilaian Untuk SD. Jakarta: Direktorat Pendidikan Dasar dan Menengah.

Kosasih, E. 2014.Strategi Belajar dan Pembelajaran Implementasi Kurikulum 2013. Bandung: Yrama Widya.

Kozhevnikov, V. V. 2019. The Hermeneutic Method in Modern Domestic Jurisprudence. Budapest International Research and Critics Institute-Journal (BIRCI-Journal) (2): $39-49$ 
Littlejohn, Stephen W \& Karen A. Foss. 2009. Teori Komunikasi, Jakarta: Salemba Humanika.

Muhammad, Arni. 2005. Komunikasi Organisasi. Jakarta: Bumi Aksara

Majid, Abdul dan Chaerul Rochman. 2014. Pendekatan Ilmiah dalamImplementasi Kurikulum 2013. Bandung: Remaja Rosdakarya.

Mulyana, Deddy. 2008. Ilmu Komunikasi: Suatu Pengantar. Bandung: Remaja RoSDakarya

Narwanti, Sri. 2011. Pendidikan Karakter. Yogyakarta : Familia

Purwanto, M. Ngalim. 2002. Psikologi Pendidikan. Bandung: Remaja Rosdakarya.

Siregar, M. 2019. Pedagogical Translation Use by Scientific Approach in Teaching English. Budapest International Research and Criticsin Linguistics and Education (BirLE) Journal (2): 111-119. 